\title{
Polymorphism in spa gene of Staphylococcus aureus from bovine subclinical mastitis
}

\author{
Taruna Bhati ${ }^{1}$, Prerna Nathawat ${ }^{1}$, Sandeep Kumar Sharma ${ }^{2}$, Rahul Yadav ${ }^{1}$, Jyoti Bishnoi ${ }^{1}$ and Anil Kumar Kataria ${ }^{1}$
}

1. Department of Veterinary Microbiology and Biotechnology, College of Veterinary and Animal Science, Rajasthan University of Veterinary and Animals Sciences, Bikaner, Rajasthan, India; 2. Department of Veterinary Microbiology and Biotechnology, Post Graduate Institute of Veterinary Education and Research, Rajasthan University of Veterinary and Animals Sciences, Bikaner, Rajasthan, India.

Corresponding author: Taruna Bhati, e-mail: vetcvas.bhati@gmail.com, PN: nathawatprerna@gmail.com, SKS: drsharmask01@gmail.com, RY: drrahul16889@gmail.com, JB: jyotibishnoi88@gmail.com, AKK: akkataria1@rediffmail.com

Received: 06-01-2016, Accepted: 18-03-2016, Published online: 28-04-2016

doi: 10.14202/vetworld.2016.421-424 How to cite this article: Bhati T, Nathawat P, Sharma SK, Yadav R, Bishnoi J, Kataria AK (2016) Polymorphism in spa gene of Staphylococcus aureus from bovine subclinical mastitis, Veterinary World, 9(4): 421-424.

\begin{abstract}
Aim: The virulence-associated protein-A of Staphylococcus aureus, encoded by spa gene shows a variation in length in different strains. In this study, the spa gene variation in $S$. aureus strains was studied which were isolated from subclinical cases of bovine mastitis.

Materials and Methods: About 38 isolates of $S$. aureus were recovered from Holstein-Friesian (HF) crossbred ( $\mathrm{n}=16)$ and Rathi cattle $(\mathrm{n}=22)$ with subclinical mastitis as per standard procedures, and these isolates were subjected to amplification of spa gene (X-region) by polymerase chain reaction and calculation of number of tandem repeats were done.

Results: Of the 16 isolates from H-F crossbred cattle, all with the exception of one isolate produced spa amplicon. Seven isolates produced amplicons of $200 \mathrm{bp}$, one produced $160 \mathrm{bp}$, and other seven produced spa amplicon of $150 \mathrm{bp}$ with calculated number of 6,5 , and 4 repeats, respectively, whereas nine different types of amplicons were produced by $22 \mathrm{~S}$. aureus isolates from Rathi cattle, viz., 280, 250, 240, 200, 190, 180, 170, 150, and 140 bp with 10, 8, 8, 6, 6, 6, 5, 4, and 4 repeats, respectively. One of the isolates from Rathi cattle produced two spa amplicons (150 and $190 \mathrm{bp}$ ).
\end{abstract}

Conclusion: A greater polymorphism was observed in the $S$. aureus isolates from Rathi cattle than from H-F crossbreds with subclinical mastitis.

Keywords: cattle, polymorphism, protein-A, spa gene, Staphylococcus aureus, subclinical mastitis.

\section{Introduction}

Bovine mastitis is a well-known challenge to dairy industry in India. It affects the economy of farmers and hence of the country leading to an estimated annual loss of around US \$526 million [1]. Staphylococcus aureus is the most important pathogen associated with various clinical forms of mastitis [2]. Among the various clinical forms of mastitis caused by $S$. aureus, subclinical cases have special importance as they go unnoticed and affect production performance of animal to a large extent [3].

The development and severity of mastitis depend on the production of virulent protein known as protein-A [4]. This protein is encoded by spa gene which has been shown to have a high degree of variability in size [5]. This variation in the spa gene comes from the differences in the repetitive variable number of $24 \mathrm{bp}$ repeats in X-region of gene. The number of

Copyright: Bhati, et al. Open Access. This article is distributed under the terms of the Creative Commons Attribution 4.0 International License (http://creativecommons.org/licenses/by/4.0/), which permits unrestricted use, distribution, and reproduction in any medium, provided you give appropriate credit to the original author(s) and the source, provide a link to the Creative Commons license, and indicate if changes were made. The Creative Commons Public Domain Dedication waiver (http://creativecommons.org/ publicdomain/zero/1.0/) applies to the data made available in this article, unless otherwise stated. these 24 bp repeats varies among different strains of $S$. aureus and hence can be used as a molecular tool in studying the genetic diversity among the Indian strains of $S$. aureus for epidemiological tracing of source of infection and comparing the differences in virulent phenotypes among various strains. Although a lot of work has been conducted in typing of $S$. aureus from human cases in India [6-8], very limited work has been done in studying the genetic diversity using spa gene of $S$. aureus strains originating from bovine mastitis [9].

In view of the above facts, the present investigation was designed to study the polymorphism of spa gene (X-region) and evaluate its applicability in differentiating the Indian $S$. aureus strains of bovine origin.

\section{Materials and Methods \\ Ethical approval}

This study was conducted following approval by the research committee and Institutional Animal Ethics Committee Guidelines were followed.

\section{Isolation of $\boldsymbol{S}$. aureus \\ Sampling}

Eighty-five milk samples were collected during early morning hours in sterilized test tubes from 
Holstein-Friesian (H-F) crossbred and Rathi cattle from different locations in Bikaner (Rajasthan, India). The samples were immediately taken to the laboratory for further processing on ice.

\section{Somatic cell counting (SCC)}

A $0.1 \mathrm{ml}$ amount from each properly shaken milk samples was withdrawn with Pasteur Pipette and spread evenly on a glass slide to count the SCC as per the method described earlier [10].

\section{Identification of $\boldsymbol{S}$. aureus}

All the milk samples which showed SCC corresponding to subclinical mastitis were processed for isolation of $S$. aureus. Phenotypic and biochemical identification of isolates were done as per the standard protocol [11]. The isolates were further genotypically confirmed by $23 S r R N A$ species-specific polymerase chain reaction (PCR) using forward primer-1 (5'-AC GGAGTTACAAAGGACGAC-3') and reverse prime r-2 (5'-AGCTCAGCCTTAACGAGTAC-3') [12].

\section{Amplification of spa gene}

The amplification of spa gene encoding protein-A wasdoneasdescribedbyFrenay etal.[13]withslightmodifications using 5'-CAAGCACCAAAAGAGGAA-3' (F) and 5'-CACCAGGTTTAACGACAT-3' (R) primers. PCR was performed in $0.2 \mathrm{ml}$ thin-walled PCR tubes. The PCR mixture contained a final concentration of $10 \mathrm{mM}$ Tris- $\mathrm{HCl}, \mathrm{pH} 9.0,50 \mathrm{mM} \mathrm{KCl,} 3.5 \mathrm{mM}$ $\mathrm{MgCl}_{2}, 1.0 \mu \mathrm{M}$ concentration of each primer, $0.2 \mathrm{mM}$ concentrations of each 2'-deoxynucleoside 5'-triphosphate and 1.0 U of Taq DNA polymerase. The PCR was performed in Palmcycler (Corbett Research, Australia) using following cycling parameters: Initial 34 cycle of amplification (denaturation at $94^{\circ} \mathrm{C}$ for $60 \mathrm{~s}$, primer annealing at $55^{\circ} \mathrm{C}$ for $60 \mathrm{~s}$ and primer extension at $70^{\circ} \mathrm{C}$ for $60 \mathrm{~s}$ ), and final extension at $72^{\circ} \mathrm{C}$ for $5 \mathrm{~min}$. Two $\mu$ l of trekking dye was added to the PCR products and were resolved in 1.2\% agarose gels prepared in $1 \times \mathrm{TBE}$ buffer containing $0.5 \mu \mathrm{g} / \mathrm{ml}$ of ethidium bromide. $100 \mathrm{bp}$ DNA ladder was used as molecular marker and the amplification products electrophoresed for $1 \mathrm{~h}$ at $100 \mathrm{~V}$. The gel was then visualized under U.V. Transillumination and photographed. Calculation of a number of tandem repeats $(\mathrm{N})$ in PCR amplified spa gene product was done using the formula given by Frenay et al. [13]. Mathematically, formula is given as:

Size of amplified spa gene product -

$$
\mathrm{N}=\frac{\text { Size of primers }(\text { forward }+ \text { reverse })}{24}
$$

\section{Results}

Out of the 85 milk samples, 38 milk samples showed SCC in the range of $200 \times 10^{3}$ to $500 \times 10^{3}$ cells $/ \mathrm{ml}$ corresponding to subclinical cases of mastitis as per the IDF (2005) criterion [14]. The SCC has been detected to be the most reliable test and closest to the bacteriological results for SCM in dairy cows by Sharma et al. (2010) [15]. A total of 38 isolates of $S$. aureus were isolated from these samples and identified on the basis of cultural and biochemical properties. All 38 isolates produced an amplicon of 1,250 bp in species-specific PCR targeting $23 \mathrm{~S} r R N A$ gene. Out of 38 isolates, 16 were isolated from $\mathrm{H}-\mathrm{F}$ crossbred cattle and 22 from native Rathi cattle.

In the present investigation, out of 16 isolates from H-F crossbred cattle, 15 strains produced spa amplicons, whereas one isolate did not produce any amplified product (Figures-1 and 2). Seven isolates produced amplicons of $200 \mathrm{bp}$, one produced $160 \mathrm{bp}$ amplicon, and other seven produced amplicon of 150 bp with calculated number of 6, 5, 4 repeats, respectively (Table-1). The spa gene X-region amplicons produced by 22 isolates from Rathi cattle were of greater variability (Figures-2 and 3) than that in isolates from $\mathrm{H}-\mathrm{F}$ crossbred cattle as nine different types of amplicons were obtained of size 280, 250, $240,200,190,180,170,150$, and 140 bp with calculated number of $10,8,8,6,6,6,5,4$, and 4 repeats, respectively (Table-2). The amplicon of $150 \mathrm{bp}$ size was found to be produced by maximum (15 isolates) number of isolates followed by amplicons of $200 \mathrm{bp}$ (11 isolates) and 280 and $240 \mathrm{bp}$ (three each). One isolate from Rathi cattle produced two bands of spa amplicons (150 and $190 \mathrm{bp}$ ).

\section{Discussion}

The PCR amplification of spa gene (X-region) yielded amplicons similar to that recorded by Salasia et al. [16] who obtained nine different sized amplicons

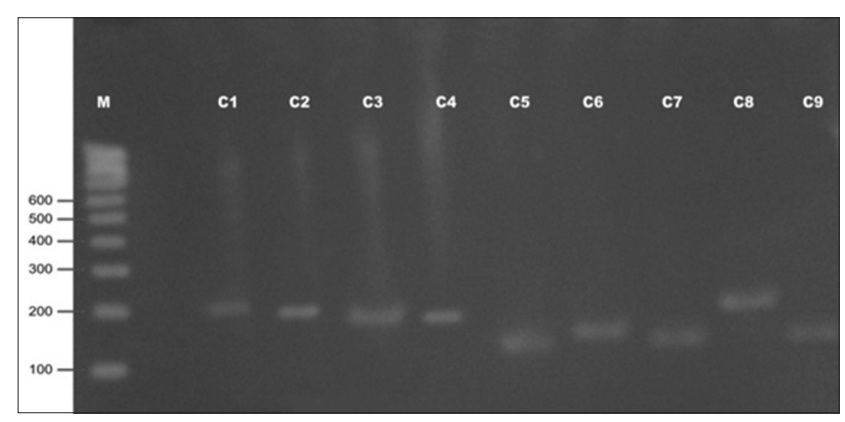

Figure-1: Polymerase chain reaction amplicons of spa gene (X-region) of Staphylococcus aureus isolates from Holstein-Friesian crossbred cattle (C1-C9) with subclinical mastitis.

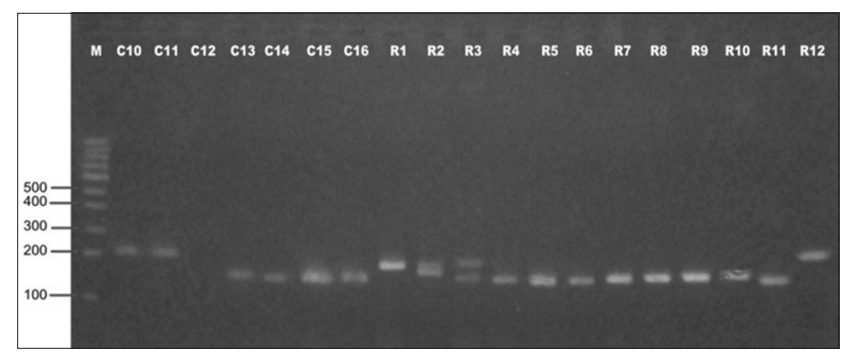

Figure-2: Polymerase chain reaction amplicons of spa gene (X-region) of Staphylococcus aureus isolates from Holstein-Friesian crossbred cattle (C10-C16) and Rathi cattle (R1-R12) with subclinical mastitis. 
of 100-340 bp in S. aureus isolates from bovine subclinical mastitis. Bystron et al. [17] also recorded 10 different sizes of spa amplicons in the $S$. aureus isolates from unprocessed cow milk, but their amplicon size varied from 3 to 14 repeats having the highest frequency of eight to 10 repeats. In our study, however, the size varied from 4 to 10 repeats with a maximum frequency of four repeats.

The spa types in this study corroborated the earlier observations of Karahan et al. [18] who also carried out spa typing of $S$. aureus strains isolated from bovine subclinical mastitis and recorded nine spa types with amplicons ranging from 100 to $320 \mathrm{bp}$ where most of the spa types were similar to that obtained in this study. However, contrarily, they obtained spa amplicons with $290 \mathrm{bp}$ and 10 repeat units as predominant spa type, whereas in our study $150 \mathrm{bp}$ spa amplicons with four repeats were predominant.

In our study, only seven of the isolates produced spa amplicons with calculated number of more than seven repeats. Freney et al. [19] reported that most

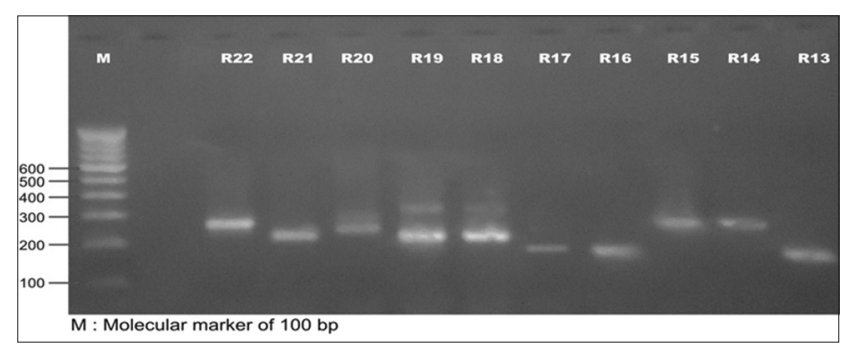

Figure-3: Polymerase chain reaction amplicons of spa gene (X-region) of Staphylococcus aureus isolates from Rathi cattle (R13-R22) with subclinical mastitis.

Table-1: spa gene (X-region) polymorphism in S. aureus isolates from $\mathrm{H}-\mathrm{F}$ crossbred cattle with subclinical mastitis.

\begin{tabular}{llccc}
\hline $\begin{array}{l}\text { Serial } \\
\text { number }\end{array}$ & $\begin{array}{l}\text { Isolate } \\
\text { numbers }\end{array}$ & $\begin{array}{c}\text { Total } \\
\text { isolates }\end{array}$ & $\begin{array}{c}\text { spa gene } \\
\text { amplicon } \\
\text { (bp) }\end{array}$ & $\begin{array}{c}\text { Total number } \\
\text { of repeats }\end{array}$ \\
\hline 1 & C1, C2, C3, & 7 & 200 & 6 \\
& C4, C8, & & & \\
& C10, C11 & & 160 & 5 \\
3 & C6 & 1 & 160 & 4 \\
& C5, C7, C9, & 7 & 150 & \\
& C13, C14, & & & \\
\hline
\end{tabular}

S. aureus=Staphylococcus aureus, $\mathrm{H}-\mathrm{F}=$ Holstein-Friesian epidemic MRSA strains harbored more than seven repeats while non-epidemic MRSA strains contained seven or fewer repeats. They discussed that a longer $\mathrm{X}$-region results in a better exposition of the $\mathrm{Fc}$ binding region of protein-A thereby facilitating colonization on both surfaces and contributing to the epidemic phenotypes. Considering the above fact, in the present investigation less number of isolates were detected to be pathogenic in regards to spa typing.

One isolate from Rathi cattle produced two bands of spa amplicons (150 and $190 \mathrm{bp}$ ) which are in conformity to the earlier observation by Rathore et al. [20] who recorded two spa bands in one isolate of $S$. aureus isolated from camel skin wounds. One of the 38 isolates did not produce spa amplicon. The absence of spa-X region gene has also been reported by Kalorey et al. [21] in subclinical mastitis, Momtaz et al. [22] from bovine clinical and subclinical mastitis, Salem-Bekhit et al. [23] in bovine mastitis isolates, and Shakeri et al. [24] in healthy carriers and human patients.

\section{Conclusion}

This study revealed polymorphism in spa $\mathrm{X}$-region gene amplicons of $S$. aureus obtained from subclinical mastitis cases. A greater polymorphism was observed in the isolates from native breed. Based on the number of repeats, it was deduced that in this study though both pathogenic and non-pathogenic strains were recovered from sub-clinical mastitis cases but nonpathogenic strains were more in number.

\section{Authors' Contributions}

AKK was the major guide of my MVSc research work and he planned and designed the study. This work is a part of my MVSc thesis. RY and PN helped in conducting the Laboratory work. Lab analysis was carried out by SKS and JB. The manuscript was revised and edited under the guidance of AKK. All authors participated in writing and revision process and approved of the final manuscript.

\section{Acknowledgments}

The first author wishes to acknowledge the institutional fellowship provided by the Rajasthan University of Veterinary and Animal Sciences (RAJUVAS) Bikaner for MVSc thesis work. The

Table-2: spa gene (X-region) polymorphism in S. aureus isolates from Rathi cattle with subclinical mastitis.

\begin{tabular}{llcc}
\hline Serial number & Isolate numbers & Total isolates & spa gene amplicon (bp) \\
\hline 1 & R14, R15, R22 & 3 & 280 \\
2 & R20 & 1 & 250 \\
3 & R18, R19, R21 & 3 & 240 \\
4 & R12, R13, R16, R17 & 4 & 200 \\
5 & R3 & 1 & 190,150 \\
6 & R1 & 1 & 180 \\
7 & R2 & 1 & 170 \\
8 & R4, R5, R6, R7, R8, R9, R10 & 7 & 150 \\
9 & R11 & 1 & 140 \\
\hline
\end{tabular}

S. aureus=Staphylococcus aureus

Veterinary World, EISSN: 2231-0916 
authors are highly thankful to the Department of Veterinary Microbiology and Biotechnology, College of Veterinary and Animal Sciences, RAJUVAS, for providing necessary facilities to carry out the research work.

\section{Competing Interests} interests.

The authors declare that they have no competing

\section{References}

1. Dua, K. (2010) Incidence, etiology and estimated economic losses due to mastitis in Punjab and India - An update. Indian Dairyman, 53: 41-48.

2. Aires-de-Sousa, M., Parente, C.E.S., Vieira-da-Motta, O., Bonna, I.C., Silva, D.A. and De Lencastre, H. (2007) Characterization of Staphylococcus aureus isolates from buffalo, bovine, ovine, and caprine milk samples collected in Rio de Janeiro State, Brazil. Appl. Environ. Microb. 73: 3845-3849.

3. Suleiman, A.B., Kwaga, J.K.P., Umoh, V.J., Okolocha, E.C., Muhammed, M., Lammler, C., Shaibu, S.J., Akinden, O. and Weiss, R. (2012) Macro-restriction analysis of Staphlyococcus aureus isolated from subclinical bovine mastitis in Nigeria. Afr. J. Microbiol. Res. 6(33): 6270-6274.

4. Mitra, S.D., Velu, D., Bhuvana, M., Krithiga, N., Banerjee, A., Shome, R., Rahman, H., Ghosh, S.K. and Shome, B.R. (2013) Staphylococcus aureus spa type t267, clonal ancestor of bovine subclinical mastitis in India. $J$. Appl. Microbiol., 14(6): 1604-1615.

5. Brandt, K.M., Mellmann, A., Ballhausen, B., Jenke, C., van der Wolf, P.J., Broens, E.M., Becker, K. and Kock, R. (2013) Evaluation of multiple-locus variable number of tandem repeats analysis for typing livestock-associated methicillin-resistant Staphylococcus aureus. PLoS One, 8(1): 54425.

6. Nadig, S., Velusamy, N., Lalitha, P., Kar, S., Sharma, S. and Arakere, G. (2012) Staphylococcus aureus eye infections in two Indian hospitals: Emergence of ST772 as a major clone. Clin. Ophthalmol., 6: 165-73.

7. Mehndiratta, P.L., Bhalla, P., Ahmed, A. and Sharma, Y.D. (2009) Molecular typing of methicillin-resistant Staphylococcus aureus strains by PCR-RFLP of spa gene: A reference laboratory perspective. Indian J. Med. Microbiol., 27(2): 116-122.

8. Dhawan, B., Rao, C., Udo, E.E., Gadepalli, R., Vishnubhatla, S. and Kapil, A. (2014) Dissemination of methicillin-resistant Staphylococcus aureus SCCmec type IV and SCC mec type V epidemic clones in a tertiary hospital: Challenge to infection control. Epidemiol. Infect., 2: 1-11.

9. Khichar, V., Kataria, A.K. and Sharma, R. (2014) Characterization of Staphylococcus aureus of cattle mastitis origin for two virulence - Associated genes (coa and spa). Comp. Clin. Pathol., 23(3): 603-611.

10. Prescott, S.C. and Breed, R.S. (1910) The determination of the number of body cells in milk by a direct method. $J$. Infect. Dis. 7: 632.
11. Quinn, P.J., Carter, M.E., Markey, B.K. and Carter, G.R. (1994) Clinical Veterinary Microbiology. Wolfe Publishing, Mosby-Year Book Europe Ltd., England.

12. Straub, J.A., Hertel, C. and Hammes, W.P. (1999) A 23S rRNA target polymerase chain reaction based system for detection of Staphylococcus aureus in meat starter cultures and dairy products. J. Food Protect., 62(10): 1150-1156.

13. Frenay, H.M.E., Bunschoten, A.E., Schouls, L.M., Van Leeuwen, W.J., Vandenbroucke-Grauls, C.M., Verhoef, J. and Mooi, F.R. (1996) Molecular typing of methicillin-resistant Staphylococcus aureus on the basis of protein A gene polymorphism. Eur. J. Clin. Microbiol., 15(1): 60-64.

14. International Dairy Federation, (IDF). (2005) Diagnostic potential of California Mastitis Test to Detect Subclinical Mastitis 26. IDF, Maastricht, Netherlands. p15-19.

15. Sharma, N., Pandey, V. and Sudhan, N.A. (2010) Comparison of some indirect screening tests for detection of sub-clinical mastitis in dairy cows. Bulg. J. Vet. Med., 13: 98-103.

16. Salasia, S.I., Khusnan, Z., Lammler, C. and Zschock, M. (2004) Comparative studies on phenol - and genotypic properties of Staphylococcus aureus isolated from bovine sub-clinical mastitis in central Java in Indonesia and Hesse in Germany. J. Vet. Sci., 5(2): 103-109.

17. Bystron, J., Bania, J., Lis, E., Molenda, J. and Bednarski, M. (2009) Characterisation of Staphylococcus aureus strains isolated from Cow's milk B. Vet. I. Pulawy, 53: 59-63.

18. Karahan, M., Aciki, M.N. and Cetinkaya, B. (2011) Investigation of virulence genes by PCR in Stapylococcus aureus isolates originated from subclinical bovine mastitis in Turkey. Pak. Vet. J., 31(3): 249-253.

19. Frenay, H.M.E., Theelen, J.P.G., Schouls, L.M., Vandenbroucke-Grauls, C.M.J.E., Verhoef, J., Van Leeuwen, W.J. and Mooi, F.R. (1994) Discrimination of epidemic and non-epidemic methicillin-resistant Staphylococcus aureus strains on the basis of protein A gene polymorphism. J. Clin. Microbiol., 32: 846-847.

20. Rathore, P., Kataria, A.K., Khichar, V. and Sharma, R. (2012) Polymorphism in coa and spa virulence genes in Staphylococcus aureus of camel skin origin. J. Camel. Pract. Res., 19(2): 129-134.

21. Kalorey, D.R., Shanmugam, Y., Kurkure, N.V., Chousalkar, K. and Barbuddhe, S.B. (2007) PCR-based detection of genes encoding virulence determinants in Staphylococcus aureus from bovine subclinical mastitis cases. J. Vet. Sci., 8(2): 151-154.

22. Momtaz, H., Rahimi, E. and Tajbakhsh, E. (2010) Detection of some virulence factors in Staphylococcus aureus isolated from clinical and subclinical bovine mastitis in Iran. Afr. $J$. Biotechnol., 9(25): 3753-3758.

23. Salem-Bekhit, M.M., Muharram, M.M., Alhosiny, I.M. and Hashim, M.E.S. (2010) Molecular detection of genes encoding virulence determinants in Staphylococcus aureus strains isolated from bovine mastitis. J. Appl. Sci. Res., 6(2): 121-128.

24. Shakeri, F., Shojai, A., Golalipour, M., Alang, S.R., Vaez, H. and Ghaemi, E.A. (2010) Spa diversity among MRSA and MSSA strains of Staphylococcus aureus in North of Iran. Int. J. Microbiol., 2010: Article ID: 351397, 5. 